\title{
A FUNCTIONAL LEXEMATIC ANALYSIS OF A HORROR SHORT STORY
}

\author{
María José Feu Guijarro \\ Universidad de Castilla-La Mancha
}

\begin{abstract}
RESUMEN: El propósito de este artículo es estudiar la aplicación del Modelo Lexemático Funcional al análisis del cuento de terrror. Se entiende que "el cuento de terror" es un espacio semántico en sí mismo regido por unas estructuras de categorización típicas y, por lo tanto, construido sobre los esquemas conceptuales prototípicos de su género. En este estudio analizamos en profundidad un cuento de terror de la literatura norteamericana, "Polaris" de H. P. Lovecraft, según el método de Martín Mingorance. La aplicación del MLF nos desvelará los marcos o esquemas conceptuales sobre los cuales está construida esta historia
\end{abstract}

ABSTRACT: The purpose of this article is to apply Martín Mingorance's FunctionalLexematic Approach into the analysis of horror-fiction. Horror-fiction is a closed semantic world in itself which displays its own structure of categorization. In this study we analyse in depth a horror-fiction short story by H.P. Lovecraft, "Polaris", according to Martin Mingorance's proposal. At the end of the article the complete network of the predicate conceptual schemata of the story is discussed.

The general purpose of this study is to propose L. Martín Mingorance's functional-lexematic model as a method of linguistic description for horror-fiction narrative. In this research we will explain why horror-fiction narrative, as a particular semantic world in itself, is an excellent candidate for the alluded type of linguistic analysis, and how the functional-lexematic model is capable of giving a complete account not only of the pragmatic, semantic and syntactic facts of horror-fiction narratives, but also of the cognitive conceptual schemas of knowledge that build up this type of narrative. In order to illustrate these claims we have chosen a short story by the well-known horror writer H.P. Lovecraft: "Polaris".

From a semantic perspective, horror fiction can be understood as a "semantic closed world". As many authors have pointed out ${ }^{1}$, horror fiction is a specific universe with its own argumental rules, characters and particular "dénouements" of the themes of

1. Todorov, T. (1975), Punter, D. (1980), Jackson, R. (1981), Corwell, N. (1981). 
the story. Every good reader can identify its recurrent characters (the personage of the doctor devoted to "transcendental medicine", the hero deceived by his senses, the character of "the other"...) and themes (the "dream", the topic of "the double", "the other world", "the unknown languages", "the uncanny", "the strange geometries", etc...).

This pragmatic structure entails a prototypical categorization of reality. If we are able to represent the complex network of pragmatic, syntactic, morphologic, thematic and encyclopedic elements that build up horror-fiction narratives, and decode this data in conceptual schemata, we shall attempt an enquiry into how we, human beings, categorize our fears through narration.

Before getting into further details of this analysis, it has to be said that the main aim of this article is not to study the narratological features of these type of narratives: textual author, fictional narrators, focalizers, implied spectators, fictional narratees, textual readers, etc. (Onega, S. \& García Landa, J., 1996). However, a future development of this model may include the encompassing of rhetorical aspects and the elucidation of how the point of view also contributes to the construction of horror fiction narratives. ${ }^{2}$

\section{The functional-lexematic model.}

Following Faber \& Mairal (1994)3 the theoretical points of departure of Martin Mingorance's research $\left(1984 ; 1985\right.$ a.b; 1987a,b,c; 1990) ${ }^{4}$ in lexicology and lexicography are:

a) The Lexicon should be something more than a fixed data base ${ }^{5}$, its component should be able to account for all type of lexical operations (metaphorical processes, lexical presuppositions, semantic domains, pragmatic features...).

b) Within the domain of Cognitive Linguistics there are two relevant approaches in which human perceptual experience plays a relevant role, and that underlines the importance of categorization in human cognition: Jackendoff (1983, 1987), Lakoff (1982), and Lakoff and Johnson (1980). However, these models require a theoretical linguistic framework which can account systematically for prototypical features: image schemata and semantic relationships.

2. Dik (1978)

3. This section is mostly a summary of the theoretical foundations of P. Faber \& R. Mairal (1994) "Methodological Underpinnings for the Construction of a Functional Lexicological Model" in Miscelanea: a Journal of English and American Studies, Vol. 15.

4. In Faber \& Mairal (1994).

5. Although from 1975 the Lexicon is no longer a storage of words but a grammar in itself; however it still lacks a representation of the real speaker's knowledge. 
Martin Mingorance's proposal tries to link structural semantics and prototype theory, given a frame where semantic dimensions can reflect the structure of conceptual schemata. His functional lexematic model entails the integration of Dik's Functional Grammar (1978), Coseriu's Lexematics (1977) and some basic assumptions of cognitive grammar:

1.1. It postulates a fully-specified lexicon which is a grammar in itself. The word is the central component of linguistic description, its properties bring syntactic, morphological, semantic and pragmatic information. This information is represented through the structure of "predication" or "predicative frames". "Predicative Frames" are formulae or structural schemata to express "The State of Affairs"6 which holds the following information of a predicate: lexical form, syntactic category $(\mathrm{V}, \mathrm{A}, \mathrm{N})$, number of arguments $((\mathrm{x} 1)(\mathrm{x} 2)(\mathrm{xn}) \ldots)$, and predicate restrictions of selection

(Animate) (Human) (Concrete). Predicative Frames contain the nuclei of knowledge representation.

(1) a. eatV [(x1: Anim (x1))Ag.(x2:solid food (x2))] Meta] Action.

b. eat (x1)S.Topic (x2)Obj.Foc.

1.2. The Functional Lexematic model considers human communication as the primary function of language. This involves a powerful role of the pragmatic rules: syntax and semantics are not an end in themselves but instruments that maintain a diagrammatic and iconic relationship with pragmatics.

1.3. The structure of the lexicon carries two axes: paradigmatic, and syntagmatic. In paradigmatic axes lexemes are arranged within semantic fields, adapting the theory of Coseriu's Lexematics into S.C.Dik's method of Stepwise in Lexical Decomposition: each hierarchy has one archilexeme in terms of which all the members of the field are defined i.e.:

(2) a. glanceV [x1: NP:+Animated (x1))Ag(x2:NP:+conc,+-(x2))Goal] Action. $\mathrm{df}=\left[\operatorname{lookV}(\mathrm{x} 1 \ldots(\mathrm{x} 2)) \mathrm{Ag} .(\mathrm{x} 2 \ldots(\mathrm{x} 2)) \mathrm{Go} .\left(\mathrm{y} 1: \mathrm{Adv}^{\wedge}\right.\right.$ quickly^$\left.(\mathrm{y} 1)\right)$ Cir-Manner]Action.

As Faber \& Mairal pinpoint, there exists an iconic diagrammatic relationship between the two axes, and it is this relationship which gives rise to the derivation of cognitive conceptual schemata within the lexicon. This means that the lexicon is conceived as a base for knowledge representation and that cognitive conceptual

6. The State of Affairs combined with the features "control" and "dynamism" provides four general types: Actions [+C+D], Processes[-C+D], States [-C-D] and Positions[+C-D]. 
schemata are good candidates for the representation of the non-perceptual part of language users, non-linguistic knowledge.

\section{Fuctional-lexematic analysis of H.P Lovecraft, "Polaris".}

In this section we have tried to apply the functional-lexematic approach to a horror short story. Our purpose is to study the text from a conceptual perspective in order to find out the frames of knowledge from which the story has been built. The point of departure will be predicative frames and the structure of their respective definiens, since, as it has been claimed before, the structure of predication and the intersection of the paradigmatic and sintagmatic axes provide all the essential information required to formulate conceptual frames.

To make the semantic analysis easier to understand, the story has been divided into four sections according to a thematic criteria. Also, in order to help the reader, at the beginning of every section there is a summary of the plot.

First of all we will describe the domains of knowledge corresponding to each thematic section with their respective predicative frame formulae. These domains of knowledge arise from a detailed analysis of the predications. Afterwards we will show how the domains are related to each other in "conceptual schemata".

1. First Part: from "Into the North Window of my chamber..till...Sometimes, when it is cloudy, I can sleep".

Summary of the first part: The narrator, sitting by the casement of his chamber, watches the night light phenomena: under the horned waning moon the redleaved trees of the swamp mutter things to one another, down from the heights reels the glittering Cassiopeia, Charles' Wain lumbers up behind the swamp, Arcturus winks above the cemetery, Comma Berenices shimmers far off in the mysterious east, and the Pole Star glows into his window with uncanny light, like an insane watching eye which strives to convey some strange message. Only when it is cloudy the narrator can sleep.

\subsection{Domains of Knowledge}

1.1.a. [LIGHT]: It is built by "predications" connected to the "light of the stars": "glow", "shine", "glitter", "shimmer", "wink". The light of the moon is not included because in the story it plays its own role. The moon is also a prototypical image in horror fiction narratives.i.e.:

(3)shimmerV [(x1: Comma Berenices; star (x1))Zero]State.

1.1.b. [VISUAL PERCEPTION]: "predications" related to "eye perception": "watch", "leer"...i.e.:

(4) watchV [(x1: I,(narrator)(x1))Exp.(x2: "that star" (x2))Go.]Process. 
1.1.c. [POSITION]: "predications" meaning having a certain position (with or without MOTION): "sit", "reel", "lumber up", "from above the cemetery on the low hillock", "from the same place", etc... i.e:

(5)reelV [[(x1: Cassiopeia (x1))Po][(y1: "down from the heights" $(y 1))$ Lo] Action.

1.1.d. [UNCANNY] We want to conceptualize through this area of knowledge a series of emotional adjectives and expressions relevant to horror-fiction whose meaning gives to the nouns they are qualifiying a sense of "uncanny": "insane watching eye", "uncanny light", "hellish hours", "hideously", etc...

1.1.e. [LANGUAGE]: "predications" whose "definiens" is related to the semantic field of "language":"mutter","convey","message":

(6)mutterV[(x1:NP "the red leaved-trees" (x1))Fo.

(x2:NP"things to one an other")Go.)]Action.

1.1.f. [CEASE OF VISUAL PERCEPTION]: semantic field related to the "absence of light": "clouds" (see, (7)).

1.1.g. [SLEEP]: semantic field related to "cease of conciousness": "sleep".i.e.:

(7) sleepV [(x1:NP narrator(x1))Zero.][(y1:adv:"when it is cloudy" (DARKNESS)(y1))Time (y2:adv: "sometimes"(y2)) Time]State

\section{1.h. [MOON]:}

(8) mutterV[[(x1:NP “the red leaved-trees" (x1))Ag. (x2:NP"things to one an other")Go.][(y1:PP "under the horned waning moon" (light)(y1))location] Action.

\section{1.i. [MESSAGE]}

(9) striveV[[(x1:the Pole Star(x1))Ag.(x2:"to convey some message")Go.] Action

\subsection{Relationships between "domains of knowledge":}

\subsection{1. [POSITION]-[VISUAL PERCEPTION]-[LIGHT]}

(10) a. sitV [[(x1:NPnarrator (x1))Po][(y1:PP "by the casement"

(y1))Location]Situación e

b. watchV [(x1:NPnarrator(x1))Exp/Ag..(x2: NP"that star"(x2))] Action.

\subsection{2. [POSITION]-[LIGHT]-[UNCANNY]}

(11) leerV [[(x1:NP "the Pole Star" (x1)Fo.] [(y1:PP"from the same place" (y1))Locative (y2:PP"in the black vault"(y2))Lo (y3:PP:"winking hide- 
Ma JOSÉ FEU GUIJARRO

ously(uncanny) like an insane (uncanny) watching eye"(y3))Manner] Process.

1.2.3. [MOON]-[LANGUAGE] (see, (8))

\subsection{4. [CEASE OF VISUAL PERCEPTION][SLEEP]}

(12) sleepV [(x1:NP narrator(x1))Zero.][(y 1:adv:"when it is cloudy" (DARKNESS)(y1))Time (y2:adv:"sometimes"(y2)) Time]State.

\subsection{5. [LIGHT]-[MESSAGE]}

(13) a. striveV[[(x1:"the Pole Star"(x1))Ag.(x2: “to convey some message”) Go.] Action

b. recallV[(x1:the Pole Star (x1))Ag.(x2:"nothing save that it once had a message to convey" (x2))Go.]Action.

1.3. Predicate Conceptual Schemata: From the relationships displayed above between the domains of knowledge the following predicate schemata can be inferred:

I.

[LIGHT-NIGHT PERCEPTION]-[HUMAN COGNITION]-[UNCANNY]

[V.PERCEPTION][STAR-LIGHT][UNCANNY]-[MOON][LANGUAGE]-[STAR-LIGHT][MESSAGE]

II.

[CEASE OF LIGHT-NIGHT PERCEPTION]-[CEASE OF COGNITION]-[SLEEP]

This first part of the story is built up on contraries: [HUMAN COGNITION] is connected to the perception of [LIGHT NIGHT] (the moon and the stars) and the [UNCANNY]; the other size of the coin is the [CEASE OF LIGHT PERCEPTION] or the [CEASE OF HUMAN COGNITION] related in this case to [SLEEP] in the sense of [INACTIVITY].

Therefore [COGNITION] bound to [LIGHT PERCEPTION] is the central conceptual frame, as this relationship is positive or negative, two other frames show up: [THE UNCANNY] or [SLEEP].

2. Second Part: From "well do I remember..." till where the Pole Star peeps into my north window each night".

Summary: The narrator sees a city on the cloudy nights when he can sleep. It was under the horned waning moon that he saw this city for the first time, its walls and towers were made of ghastly marble, and in the zenith glowed the watching Pole Star. When the star Red Aldebaran had crawled a quarter of the way around the horizon he saw forms, strange and familiar, that walked and talked under the horned waning moon. He understood their language although it was unlike any other language and he wanted to speak to the grave men who conversed each day in the public squares of this city. 


\subsection{Domains of Knowledge ${ }^{7}$ :}

\section{1.a. [DARKNESS]}

\section{1.b. [SLEEP]}

(14) a. comeV [[(x1:NP"the clouds" (x1))Ag.][(y1: PP"after the beam (the Pole Star)"(y1))Location] Action e

b. sleepV [[(x1:narrator(x1))Zero][(y1: "then"(y1))Time] State.

2.1.c. [CITY]: This field holds the semantic elements which built the complex idea of a city: "columns", "domes", "pavements", "streets", "pillars", "men"...i.e:

(15) [(x1: NP "its walls, its towers, its columns..." (x1)) = (x2:NP"ghastly (UNCANNY) marble")].

2.1.d. [UNCANNY]: "ghastly", "daemon" (i.e. (11)).

\section{1.e. [VISUAL PERCEPTION]}

(16) gazeV [[(x1:narrator (I)(x1))Exp/Ag.][(y1:PP"on the city"(y1))] Process.

\section{1.f. [LANGUAGE]}

(17) talkV [(x1:men (x1))Ag.(x2:wisdom (x2))Go.]Action.

2.1.g. [OTHERNESS]: This is a specific field of knowledge of horror fiction, it includes all the semantic ideas or terms related to the theme of "otherness", as can be the ideas of other language, other life or "the double", i.e.:

(18) $[(x 1:$ it (the language $))=(x 2: "$ unlike any language" $(x 2))]$

\section{1.h. [MOON]:}

(19) seeV [[(x1:narrator (I)(x2))Exp/Process.(x2:NP"the city" (x2))Go.] [(y1:PP"for the first time" (y1))Time (y2:PP"under the horned waning moon"(y2))Location]Process.

2.1.i. [INNER SELF]: This "domain of knowledge", highly important for horror-fiction, covers words or other linguistic devices related to "the self": "memory", "myself", "mind", "within my soul"... i.e:

(20) sayV[[(x1:narrator (x1))Ag.(x2:”to my self"(x2)Go.)] Action.

\section{1.j. [LIGHT]}

(21) playV[(x1:NP"the shocking coruscations PP of the daemon light" (x2))Ag.][y1:PP “over the swamp"] Action.

7. In the cases where the "definiens" of a "field of knowledge" has the same connotations as those in the first part, only one example will be given. 
Ma JOSÉ FEU GUIJARRO

\subsection{Relationships between "domains of knowledge":}

2.2.1. [DARKNESS]-[SLEEP] (i.e. (14))

2.2.2. [MOON]-[VISUAL PERCEPTION]-[CITY] (see,(15))

2.2.3. [LANGUAGE]-[OTHERNESS]

(22) talkV [[(x1:"men" (x1))Ag.][(y1:PP"under the horned waning moon" (y1)Location)(y2:"in a tongue...unlike anylanguage I had ever known" (y2) Manner)] Action.

\subsection{4. [MOON]-[CITY]-[SLEEP]}

(23) lieV [[(x1:it (the city)(x1))Zero][(y1:"still and somnolent"'(y1))Manner(y2:"under the horned waning moon"(y2))]Lo.]State.

\subsection{5. [LANGUAGE]-[INNER SELF]-[CITY]}

(24) speakV[[(x1:narrator(I)(x1))Ag.(x2:"to my mind"'(x2))Go.][(y1:"amongst the grave men who conversed each day in the public squares"(y2))Lo.] Action.

2.2.6. [LIGHT]-[UNCANNY] (see,(21))

\subsection{Predicate Conceptual Schemata:}

\section{I. a. \\ [DREAM][CEASE OF COGNITION][OTHER HUMAN REALITY] [MOON][SLEEP][HUMAN REALITY][OTHERNESS] \\ [MOON][V.PERCEPTION][CITY]-[MOON][LANGUAGE][OTHERNESS]-[MOON][CITY][SLEEP]}

\section{I. b.}

[INNER HUMAN REALITY]

[LANGUAGE][INNER SELF][CITY]

II.[AWAKENESS]

[STAR LIGHT][CONSCIOUNESS][UNCANNY]

This thematic section is also developed throughout dualities, the central element from which these contraries arise, is again [COGNITION]: [CONSCIOUSNESS] and [THE CEASE OF COGNITION].

[THE CEASE OF COGNITION] is connected with other semantic fields, most of them prototypical in horror-fiction. First of all, [THE CEASE OF COGNITION] takes places under certain semantic conditions, the narrator falls asleep [SLEEP] and it is in this state of [UNCONSCIOUNESS] or [DREAM] where he meets [THE OTHERNESS] or [ANOTHER HUMAN REALITY], symbolized in this part of the narration by the [CITY]. This [OTHER REALITY] is related to a particular type of [NIGHT LIGHT]: the [MOON]. It is beneath this light where the main character sees for the first time the [CITY], with its inhabitants. This fact brings about another duality or contradiction, because it is in the "state" of [DREAM] (cease of conciousness) where he becomes aware (conscious) of another type of reality : the [INNER 
HUMAN REALITY] or the reality of its mind. It is in this other world inside himself where the narrator finds people he likes and understands, although he has never heard their language before. From a literary point of view this is a case of what is known as the Double or Doppelgänger (Ballesteros González 1993).

On the other hand, [COGNITION] or [CONSCIOUSNESS] is interconnected in the story with semantic fields already found in the first part: the [STAR LIGHT] and the [UNCANNY]. In the first case, [STAR LIGHT] specifically refers to the light of the Pole Star, not to the [NIGHT LIGHT], as in the first part. Finally, it is important to recall that what really creates the opposition between the perception of the two sides of [COGNITION] is the conceptual field of [THE UNCANNY]. This field, made mostly by adjectives such as: hellish, insane watching eye, hideous, daemon, etc..., represents the narrator's voice, and gives the conceptual fields the emotional content of horror fiction narrative. Therefore, this field sets up the two main dualities in this section we are writing about: [DREAM-INNER HUMAN REALITY] and [AWAKENESS], both connected with two different types of cognition, and the last one underlined by the sense of [UNCANNY].

\section{Third Part:}

From "One night as I listened the discourse in the large square..." till "...that lies betwixt the peaks of Noton and Kadiphonek".

Summary: One night the narrator felt a physical change and perceived he had already a body in the city of Olathoe. He was inside the city listening to the speech of his friend Alos, a true man and a patriot. Alos was the commander of all the forces against the Inutos, squat, hellish, yellow fiends who had ravaged five years ago the confines of his kingdom. Alos denied to the narrator a warrior's part, for he was feeble and given to strange faintings. However, as the narrator's eyes where the keenest of the city, he was sent to the watchtower of Thapnen to serve as the eyes of the army. He was to give the signal of fire which would warn the waiting soldiers and save the town from immediate disaster.

\subsection{Domains of Knowledge:}

3.1.a. [OTHERNESS]: Theme of "The Double": Alos ("the other", in Ancient Greek). i.e.:

(25) speakV [(x1:"my friend Alos" (narrator's friend)(x1)] Action.

\section{1.b. [LANGUAGE]:}

(26) listenV [(x1:narrator (x1)) Exp/Proc.(x2: the discourse (x2))Go.] Action

3.1.c. [PERCEPTION]: This semantic area encloses predications whose meaning is "general feeling" or "general perception": "feel", "percieve".i.e.:

(27) feelV [(x1: narrator (I)(x2)) Exp/Proc.(x2: a change (x2))Go]State. 
3.1.d. [PLEASURE]: This area includes predications whose meaning is related to "pleasure": "please".i.e.:

(28) pleaseV [(x 1: “his speech" (Alos)(x2))Ag.(x2:my soul(x2)) Exp/Proc)]Action

3.1.f. [GOODNESS]: Semantic space filled by predications with the idea of "truth", "valor", etc...i.e.:

(29) $[(x 1:$ : Alos's speech" $(x 1))=(x 2$ : "the speech of a true man and a patriot"(x2))]

3.1.g. [EVIL]: Semantic space that encloses predications related to the idea of "evil": "fiend", "ravage", "besiege", etc...i.e.:

(30) ravageV[[(x1: "the hellish yellow fiends (Inutos)"(x2))Ag.(x2:"the confines of our country"(x2)Go)]Action.

\section{1.h. [VISUAL PERCEPTION]}

(31) $[(\mathrm{x} 1$ : "my eyes (narrator's eyes $)(\mathrm{x} 1))=(\mathrm{x} 2$ : "the keenest of the city" (x2))]

3.1.i. [WEAKNESS]: This semantic path of knowledge is associated with the narrator's physical state: "feeble", "strange faintings", "stress", "hardships", "excitement", "fatigue"...i.e.:

(32) $[(\mathrm{x} 1$ : narrator $(\mathrm{I})(\mathrm{x} 1))=(\mathrm{x} 2$ : "feeble and given to strange faintings"(x2)) $]$

3.1.j. [MESSAGE]: "message", "signal", etc...i.e.:

(33) was to giveV [(x1: “narrator" (I)(x1))Ag.(x2:”the signal”(x2)) Go.)] Action.

\section{1.k. [CITY]}

\subsection{Relationships between "domains of knowledge":}

3.2.1. [LANGUAGE]-[PERCEPTION]

(34) feelV[[(x1: "narrator" (I))Exp/Procs.(x2: "a change" (x2)) Go.] [y1: Adv:"When I listen to the discourse in the large square"(y1)]Manner]Action.

3.2.2. [LANGUAGE]-[PLEASURE]-[OTHERNESS] (see, (29)).

3.2.3. [CITY]-[GOODNESS]-[EVIL] (see (30)).

\subsection{4. [VISUAL PERCEPTION]-[MESSAGE]}

(35) sendV[(x1:"Alos"(x1))Ag.(x2: "me"(x2))Bef.(x3: "to the watchtower to serve as the eyes of our army"(x3)Go.]Action.

\subsection{5. [VISUAL PERCEPTION]-[WEAKNESS]}

(36) a.[(x1:"narrator" $(\mathrm{x} 1))=(\mathrm{x} 2$ : "feeble and given to strange faintings"'(x2))] b. $[(x 1$ :narrator's eyes $(x 1))=(x 2$ :"the keenest of the city" $(x 2))]$ 


\title{
3.3. Predicate Conceptual Schemata:
}

\author{
I. a. \\ [ANOTHER HUMAN COGNITION][PLEASURE] \\ [GENERAL PERCEPTION][COMMUNICATION][PLEASURE][OTHERNESS] \\ [LANGUAGE][PERCEPTION]-[V.PERCEPTION][MESSAGE]- \\ [LANGUAGE][OTHERNESS][PLEASURE]
}

I. b.

[HUMAN DUALITY]

[SOUL][BODY]

[GOODNES][EVIL]-[MIND][BODY]

[CITY][GOODNESS][EVIL]-[V.PERCEPTION][NERVOUS WEAKNESS]

The relationships between the conceptual schemata a and $b$ entails:

[DREAM]

[HUMAN DUALITY][ANOTHER HUMAN COGNITION][PLEASURE]

This part continues with the duality brought by [HUMAN COGNITION], adding interesting new elements to the development of the conceptual schemata of this story. Inside this other form of reality, already introduced in the second part of this narrative that is [DREAM], other contraries appear, all concerning [HUMAN DUALITY], and the above mentioned literary topic of the "double":

a) the duality of human soul [GOODNESS] and [EVIL], represented by the inhabitants of the city, full of wisdom and culture, and by their contraries, the Inutos, hellish and uncultivated fiends;

b) the duality of man himself, pointed out by the writer through the character of Alos ("the other" in Greek), complementary double of the narrator. Alos, a true man and a warrior, represents the [BODY] meanwhile the narrator plays the role of [MIND]. This duality needs further explanation: the concept of [MIND] is connected in the story to [COGNITION] and the most important sense the narrator has to develop his cognition processes: [VISUAL PERCEPTION]. However, this cognitive ability of the narrator -he is "the keenest eyes of the city"- has its physical counterpart: he suffers from [NERVOUS WEAKNESS] and he is not capable of using his body to help his city. This duality is going to condemn him to a eternal nightmare, as it occurs in the last part.

4. Last part: From "But I stood in the tower's topmost chamber..." till "...the end..."

Summary: As the narrator was standing in the tower, he beheld the horned waning moon, red and sinister, meanwhile, through an opening in the roof, glittered the Pole Star leering as a fiend and a tempter. Its spirit whispered evil counsel to the narrator, soothing him into a traitorous somnolence. Vainly did the narrator struggle 
with his drowsiness, his head drooped to his breast, and when he looked up again he was in a dream, with the Pole Star grinning at him through his window. Dreamcreatures mock him whilst he sleeps. He has failed to do his duty and betrayed the marble city. The Pole Star, evil and monstrous, leers down from the black vault winking hideously like an insane watching eye.

\subsection{Domains of Knowledge ${ }^{8}$ :}

\section{1.a. [MOON]}

\section{1.b. [VISUAL PERCEPTION]}

\section{1.c. [UNCANNY]}

\section{1.d. [LIGHT]}

\section{1.e. [EVIL]}

\section{1.h. SLEEP}

4.1.i. [UNFAITHFULNESS]: related to predications meaning: "deceive", "mock", "laugh at", "deride"...i.e.:

(37) derideV [(x1: "the shadows of my dreams"(x2)Ag)]Action.

4.1.j. [FAILURE]: related to predications meaning: "fail", "betray", "prove false", ...i.e.:

(38) betrayV [(x1:"narrator" (x1))Ag.(x2:"the marble city of Olathoe" (x2)Go.)]Action.

\section{1.k. [DISPAIR]:}

(39) screamV[[(x1:"narrator" (x2))Ag][(y1:"in my shame and dispair" (y1))Manner] Action.

\subsection{1. [COMMUNICATION](see,(44))}

\subsection{Relationships between "Domains of Knowledge".}

\subsection{1. [MOON]-[UNCANNY]-[VISUAL PERCEPTION]}

(40) beheldV[(x1:"narrator"'(x1))Exp.(x2:"the horned waning moon, red and sinister"(x2)Go.] Process.

\subsection{2. [LIGHT]-[EVIL]}

(41) a.glitterV $[(\mathrm{x} 1$ :the Pole Star (x1))Zero]State e

b. leerV [[(x1: the Pole Star (x1))Exp/Ag.][(y1:'like an insane watching eye" (y1))] Process.

8. In this section in the cases where the fields of knowledge have the same content as in other sections no examples will be given. 


\title{
4.3.3. [LIGHT]-[SLEEP]
}

(42)whisperV[(x1:"its spirit"(The Pole Star)(x1))Ag. (x2:"evil counsel soothing me to traitorous somnolence"(x2)Go.)]Action.

\subsection{4. [SLEEP]-[FAILURE]}

\subsection{5. [SLEEP]-[DISPAIR]}

\subsection{6. [SLEEP]-[UNFAITHFULNESS]}

(43) mockV[[(x1:"the dream-creatures"(x1))Ag.(x2:"me" (x2))Go] [(y1: adv:"while I sleep")]Action.

\subsection{7. [LIGHT]-[MESSAGE]}

(44) a. striveV[[(x1:the Pole Star(x1))Ag.(x2:"to convey some message”) Go.] Action.

b. recallV[(x1:the Pole Star (x1))Ag.(x2:"nothing save that it once had a message to convey" (x2))Go.]Action.

\subsection{Predicate Conceptual Schemata:}

\author{
I. a. \\ [NIGHT LIGHT][COGNITION][SLEEP] \\ [MOON][UNCANNY][V.PERCEPTION]-[LIGHT][EVIL]-[LIGHT][MESSAGE]-[LIGHT][SLEEP] \\ I. b. \\ [SLEEP][HUMAN SUFFERING] \\ [SLEEP][FAILURE]-[SLEEP][DISPAIR]-[SLEEP][UNFAITHFULNESS] \\ The relationship between these conceptual networks entails: \\ [COGNITION][SLEEP][HUMAN SUFFERING] \\ [COGNITION]-[NIGHT LIGHT]-[SLEEP] \\ [LIGHT NIGHT][COGNITION]-[SLEEP][HUMAN SUFFERING]
}

The last part of the story reveals the other side or the duality of [DREAM]: [HUMAN SUFFERING]. The move from the enchantment of [DREAM] in the sense of [PLEASURE] to its dark opposite, [NIGHTMARE], takes place through [COGNITION]. The narrator is condemned by the Pole Star to sleep, he looses his awakeness, he is not able to carry out his mission of watcher and advise the garrison about the enemies. 
Ma JOSÉ FEU GUIJARRO

\title{
5. Conclusions
}

\subsection{Diagram of the main network of conceptual schemata in H.P.Lovecraft's "Polaris".}

\author{
I. [PERCEPTION] \\ [COGNITION] \\ [AWAKENESS] \\ [UNCANNY] \\ [HUMAN SUFFERING]=[NIGHTMARE] \\ II. [THE CEASE OF PERCEPTION] \\ [SLEEP] \\ [DREAM][PLEASURE] \\ [ANOTHER HUMAN REALITY] \\ [ANOTHER COGNITION] \\ [HUMAN DUALITY] \\ [GOOD][EVIL] [MIND][BODY] [PLEASURE][SUFFERING]
}

As it is shown in the diagram, the story is built upon a conceptual net of contraries: [PERCEPTION] plus [COGNITION] bring the narrator into two dreadful opposite realities: the reality of [AWAKENESS] and the reality of [SLEEP]. Both are linked with two different aspects of human horror, [THE UNCANNY]: in this story the horror of being awake and [THE NIGHTMARE] or the suffering inside the dreams.

The other side of the coin, [THE CEASE OF PERCEPTION], takes the narrator to [SLEEP] as well; however, in this case [SLEEP] means [DREAM], and [DREAM] is associated to [PLEASURE] or [CONTENT]. The sense of [DREAM] in the story entails [ANOTHER HUMAN REALITY]-[INNER TO HUMAN BEING] and [ANOTHER TYPE OF COGNITION]. This fact leads us to another group of dualities that comes from the conceptual schema of [HUMAN DUALITY]: [GOOD] and [EVIL], [MIND] and [BODY], and [SUFFERING][PLEASURE].

Before discussing this, we would like to remind the reader of the fact that, although there are many linguistic data which we have not analysed in detail due to the lack of space such as arguments, state of affairs, syntactic relationships, etc... all are contained within the "predicative frames" and their result: the proposed network of categorization.

\section{Discussion}

We have tried to apply Martin Mingorance's functional-lexematic model to the linguistic analysis of a horror short story. As our starting hypothesis was that horror fiction is a semantic closed world in itself, we have to consider this study of "Polaris" as an example of categorization of horror in narrative. We do not mean, of course, that 
all horror stories should follow the same schemata of conceptual categorization; in the analysis of other stories different domains of knowledge and other relationships more or less prototypical should appear. However, it is our claim that many of the domains and relationships posed in this study will appear recurrently in other stories of this genre and that they will share with other horror stories a common semantic network of categorization.

\section{References}

BALLESTEROS GONZÁLEZ, A. (1993) Narciso: mito y dualidad conceptual en la literatura inglesa victoriana. Tesis Doctoral sin publicar. Madrid: Universidad Complutense.

COSERIU, E. (1977). Principios de semántica estructural. Madrid: Gredos.

CORNWELL, N. (1981). The Literary Fantastic. Hemel Hempstead: Harvester.

DIK, S. C.(1978). Functional Grammar. Dordrecht: Foris.

MARTIN MINGORANCE, L. (1984).”Lexical Fields and Stepwise Lexical Decomposition in a Contrastive English-Spanish Verb Valency Dictionary”. In Hartmann 1984: 226-236.

- (1985a).'La semántica sintagmática del adjetivo. Parámetros para la organización de un lexicón inglés/español de valencias adjetivales". Actas del II Congreso Nacional de la Asociación Española de Lingüística Aplicada. Madrid: Sociedad General Española de Librería. 329-340.

- (1985b). "Bases metodológicas para un estudio contrastivo del léxico derivado". Revista Española de Lingüística Aplicada. 1:37-54

- (1987a). "Classematics in a Functional-Lexematic Grammar of English. Actas del X Congreso de la Asociación Española de Estudios Anglo-Norteamericanos. Zaragoza:Publicaciones de la Universidad. 377-382.

- (1987b). "Semes, Semantic Classemes, and Dimensions: The Lexicological and Lexicographic Perspectives". Paper read at the XIVth International Congress of Linguists. Berlin, 10-15 August 1987.

- (1987c). "Pragmatic Features in the Lexicon of a Functional Grammar." Paper read at the International Pragmatics Conference. Antwerp, 17-22 August 1987.

- (1990). "Functional Grammar and Lexematics" in Tomaszcyk and Lewandowska-Tamaszcyk 1990: 227-253.

FABER, P. \& R. MAIRAL. (1994). "Methodological Underpinnings for the Construction of a Functional Lexicological Model". Miscelanea a Journal of English and American Studies.15: 184-217.

JACKENDOFF, M (1983). Semantics and Cognition. Cambridge (MA):MIT Press.

- (1987). "The Status of the Thematic Relations in Linguistic Theory". Linguistic Inquiry 18: 369:411. 
JACKSON, R.(1981). Fantasy: The Literature of Subversion. London: Routledge. LAKOFF, G.(1982). Categories: An Essay in Cognitive Linguistics. Trier: LAUT. LAKOFF, G. \& M. Johnson. (1980). Metaphors We Live By. Chicago: U of Chicago P. ONEGA,S. \& LANDA, G. Eds.(1996). Narratology: An Introduction. London: Longman.

LOVECRAFT, H. P. (1987). "Polaris". Omnibus 2. Dagon and Other Macabre Tales. Grafton Books. Glasgow. 31-35.

PUNTER, D. (1980). The Literature of Terror. London: Longman.

TODOROV, T. (1972). Introducción a la literatura fantástica. Tiempo Contemporáneo. Buenos Aires. 